\title{
Improving corn silage quality in the top layer of farm bunker silos through the use of a next-generation barrier film with high impermeability to oxygen
}

\author{
G. Borreani ${ }^{1,2}$ and E. Tabacco ${ }^{1}$ \\ Department of Agricultural, Forest and Food Sciences (DISAFA), University of Torino, Via L. da Vinci 44, 10095 Grugliasco, Italy
}

\begin{abstract}
This study examined the effect on the fermentation, chemical, and microbiological quality of corn silage covered with a new-generation high oxygen barrier film (HOB) made with a special grade of ethylene-vinyl alcohol $(\mathrm{EVOH}) \mathrm{compared}$ with a standard polyethylene film (PE). Two bunkers (farms 1 and 2) were divided into 2 parts lengthwise so that half of the silo would be covered with PE film and the other with HOB film. Plastic net bags with fresh chopped corn were buried in the upper layer (close to and far from the wall) and in the central part of the bunkers. During spring-summer consumption, the bags were unloaded, weighed, and subsampled to analyze the dry matter (DM) content, neutral detergent fiber and starch contents, $\mathrm{pH}$, lactic and monocarboxylic acids, yeast and mold counts, aerobic and anaerobic spore-former counts, and aerobic stability. We also determined the economic benefit of applying the novel covering. The top layer of silage conserved under the HOB film had a higher lactic acid content and lower $\mathrm{pH}$; lower counts of yeasts, molds, and aerobic and anaerobic spore-formers; higher aerobic stability; and lower DM losses than the silage conserved under the PE film. The use of the HOB film prevented almost all of the silage in the upper layer from spoiling; only 2 out of 32 samples had a mold count $>6 \log _{10}$ $\mathrm{cfu} / \mathrm{g}$. This led to a net economic gain when the HOB film was used on both farms due to the increased DM recovery and reduced labor time required to clean the upper layer, even though the HOB film cost about 2.3 times more than the PE film. Furthermore, use of the HOB film, which ensures a longer shelf life of silage during consumption, reduced the detrimental effect of yeasts, molds, and aerobic and anaerobic spore-formers on the nutritional and microbiological quality of the unloaded silage.
\end{abstract}

Received October 21, 2013.

Accepted December 20, 2013.

${ }^{1}$ Both authors contributed equally to the work described in this paper.

${ }^{2}$ Corresponding author: giorgio.borreani@unito.it
Key words: corn silage, oxygen barrier film, dry matter loss, aerobic deterioration

\section{INTRODUCTION}

Anaerobiosis is critical for successful ensilage, and it can be difficult to achieve adequate anaerobic conditions in farm silos (Wilkinson and Davies, 2013). Corn silage is particularly susceptible to aerobic deterioration when it is exposed to oxygen or in the feed bunk (Ashbell and Weinberg, 1992). Many corn silages are stored in horizontal silos and, consequently, the upper parts are exposed to air and are more prone to spoilage (Ashbell and Lisker, 1988; Borreani and Tabacco, 2010). If airtight sealing of the silo is not achieved, air penetrates the silage and aerobic microorganisms multiply, resulting in aerobic deterioration. The DM losses in the top $0.5 \mathrm{~m}$ can exceed $35 \%$ (Borreani et al., 2007). Polyethylene films have been used since the 1950s to seal bunker silos and drive-over piles because of their suitable mechanical characteristics and low costs. Because the oxygen impermeability of the plastic films used to seal silage has a great effect on reducing the top spoilage losses (Borreani et al., 2007), it is crucial to optimize the mechanical characteristics and the level of oxygen impermeability of the plastic films. Since the 1990s, the only way of improving film impermeability to oxygen has been to increase the thickness of lowdensity polyethylene (LD-PE) films (Savoie, 1988). To this aim, Savoie (1988) calculated DM losses due to LD-PE film permeability in relation to film thickness and reported losses of 2.44 to $0.32 \%$ of DM for each 30 -d period of conservation for film thickness increasing from 25 to $200 \mu \mathrm{m}$. Borreani et al. (2007) demonstrated a remarkable reduction in DM losses due to the adoption of a coextruded barrier film (oxygen barrier; OB) with polyamide (PA) as a barrier polymer to cover bunker silos. To obtain a plastic film with oxygen permeability $<100 \mathrm{~cm}^{3} / \mathrm{m}^{2} \times$ day (at standard conditions of $23^{\circ} \mathrm{C}$, $100 \mathrm{kPa}$, and $65 \%$ relative humidity), it is necessary to have a layer of PA of at least $14 \mu \mathrm{m}$ thickness in the coextruded film. The first generation of barrier films that used PA as the barrier layer had sufficient mechanical characteristics compared with a LD-PE based 
plastic films (Borreani et al. 2011). However, the film is more rigid than a conventional LD-PE film, especially when the thickness of the film is $<50 \mu \mathrm{m}$ (De Angelis, 2012). Furthermore, some farm experiences (Staples, 2009 ), in which $45-\mu \mathrm{m}$-thick polyethylene or PA oxygen barrier films were used, reported problems of fragility of the film, which led to the necessity of protecting it, not only with a tarpaulin sheet, but also with another plastic film (2-step covering system) to avoid the risk of damage during conservation.

Among the thermoplastic polymers currently available on the market, ethylene-vinyl alcohol (EVOH) offers the best barrier to oxygen. A special grade of EVOH (SoarnoL SG611B; Nippon Gohsei, Osaka, Japan) that combines high barrier properties with good mechanical characteristics such as puncture resistance, tear resistance, and stretch properties (Borreani et al., 2011) has been available since 2006. These characteristics make it suitable for the production of film for agricultural applications through blown coextrusion with polyethylene to produce 20- to $200-\mu$ m-thick plastic films. The EVOH polymer is also characterized by the absence of chlorine in its molecule, thus reducing the risk of dioxin production if it is burned. The permeability to oxygen of these polymers for a 1- $\mu \mathrm{m}$ thickness film at standard conditions $\left(23^{\circ} \mathrm{C}, 100 \mathrm{kPa}\right.$, and $65 \%$ relative humidity) is 38 for $44 \mathrm{~mol} \% \mathrm{EVOH}$, 1,375 for PA (nylon 6), and $158,000 \mathrm{~cm}^{3} / \mathrm{m}^{2} \times$ day for the LD-PE. Therefore, EVOH coextruded barrier films have allowed oxygen impermeabilities to be improved to values $<10 \mathrm{~cm}^{3} / \mathrm{m}^{2} \times$ day under standard conditions without compromising the high mechanical performance of the polyethylene-based films, thanks to the synergy of the polyethylene matrix. The availability of a new EVOH formulation, together with improvements of blowing machines (Rübbelke, 2012), have made it possible to produce a new generation of high-barrier films to cover silages (Borreani and Tabacco, 2012a). It has recently been shown that the use of oxygen barrier plastic films for ensiling can ensure a longer shelf life of silage, protecting it from spoilage and delaying the growth of pathogenic molds, which are able to produce mycotoxins that are harmful to animals and humans (Cavallarin et al., 2011; Dolci et al., 2011). This next generation of barrier films should be tested in farm conditions, to evaluate the economic benefit of this new tool for silo management and the resulting nutritional, fermentative, and microbiological quality of the silage.

Hence, the aim of the study was to assess the effect of the next generation of high oxygen barrier films, produced with a special grade of EVOH molecule that is able to improve oxygen impermeability, on fermentation quality, DM losses, yeast and mold counts at open- ing, and aerobic stability of whole-crop corn bunker silos on commercial farms.

\section{MATERIALS AND METHODS}

\section{Crop and Ensiling}

Two trials were carried out on 2 commercial farms at Saluzzo, Italy $\left(44^{\circ} 40^{\prime} \mathrm{N}, 7^{\circ} 32^{\prime} \mathrm{E}, 325 \mathrm{~m}\right.$ above sea level; farm 1) and at Rocca de Baldi, Italy $\left(44^{\circ} 27^{\prime} \mathrm{N}\right.$, $7^{\circ} 43^{\prime} \mathrm{E}, 409 \mathrm{~m}$ above sea level; farm 2) over the period 2010-2011 on corn silage in bunker silos. Whole corn crops were harvested at around the $50 \%$ milk-line stage and chopped using a conventional forage harvester to a 12-mm theoretical length of cut and ensiled within $1 \mathrm{~d}$ in bunker silos. The effects of 2 types of plastic sheet used to seal the silos (standard polyethylene vs. new oxygen barrier film) were studied. The 2 sealing treatments were (1) a single $200-\mu \mathrm{m}$-thick (6 and $8 \mathrm{~m}$ width for farm 1 and farm 2, respectively) black-onwhite polyethylene, UV-protected film (PE); and (2) a single $130-\mu \mathrm{m}$-thick $(6$ and $8 \mathrm{~m}$ width for farm 1 and farm 2, respectively) black-on-white coextruded polyethylene-special grade EVOH (SoarnoL SG611B, Nippon Gohsei) film, with a high oxygen barrier and UV protected (HOB). Furthermore, we studied the effects of the distance from the silo wall in the upper part of the silos (first $400 \mathrm{~mm}$ ) for 2 treatments: silage stored close to the wall, from 0 to $1,500 \mathrm{~mm}(\mathbf{C W})$, and silage stored far from the wall, from 1,501 to $3,000 \mathrm{~mm}$ $(\mathbf{F W})$. The bunkers had different dimensions (length $\times$ width $\times$ height of $19 \times 8 \times 2.6 \mathrm{~m}$ and $60 \times 10 \times 4.7$ $\mathrm{m}$, for farms 1 and 2, respectively) and different storage capacities (about 180 and 1,800 t of fresh silage for farms 1 and 2, respectively). Each bunker was divided into 2 parts lengthwise, and half was covered with the $\mathrm{PE}$ film and half with the $\mathrm{HOB}$ film to allow silage sampling of the 2 treatments at the same time. About 2 $m$ of each plastic sheet was placed on the side wall and turned on the top surface of the silos at the end of filling, to have an overlap of about $500 \mathrm{~mm}$ of the 2 sheets in the middle of the silos. The 2 plastic sheets were held to the silage by placing gravel bags near the side walls. During the filling of the silos, 32 plastic net bags (8 for each treatment) with well-mixed fresh material (around $7 \mathrm{~kg}$ per bag) were subsampled for pre-ensiling analyses, weighed, and buried in the upper layer of the bunker in four 4-m-apart and 10-m-apart sections for farms 1 and 2, respectively. The bags in each section were placed at 2 distances from the bunker walls $(2$ bags from 0 to $1,500 \mathrm{~mm}$ from the silo wall and 2 bags from 1,501 to $3,000 \mathrm{~mm}$ from the silo wall). Four more bags were weighed and buried in the central part of 
each bunker (half way between the top and bottom of the silo). The silos were opened for spring-summer consumption after $134 \mathrm{~d}$ and $187 \mathrm{~d}$ in farms 1 and 2, respectively. When the feedout face reached a distance of $0.5 \mathrm{~m}$ from the bags, the bags were removed from the silos for analyses. Each bag was immediately weighed and subsampled to determine the DM content (3 replicates), the fermentation profile ( 2 replicates), and the microbiological counts (2 replicates). The remaining silage was used to determine aerobic stability. Around $3 \mathrm{~kg}$ of each replicate from each treatment was placed loosely in duplicate 17-L polystyrene boxes and allowed to aerobically deteriorate at room temperature $\left(20^{\circ} \mathrm{C}\right)$. These silages were not disturbed during the recording of the temperatures. A single layer of aluminum cooking foil was placed over each container to prevent drying and contamination, but also to allow air penetration. The room temperature and the temperature of each silage were measured each hour by a data logger. Aerobic stability was defined as the number of hours the silage remained stable before increasing more than $2{ }^{\circ} \mathrm{C}$ above the ambient temperature (Ranjit and Kung, 2000). Eight core samples ( $45 \mathrm{~mm}$ in diameter and 500 $\mathrm{mm}$ long) were taken from the feedout face of each silo, weighed, and oven-dried to determine the wet bulk and DM silage densities.

\section{Quantification of Spoiled Silage and Economic Losses}

The amount of herbage ensiled was measured by weighing each load that reached the silo during filling. Spoiled silage that was discarded by farmers during silo consumption and the time needed to discard it were measured 8 times by weighing the amount of silage that had to be discarded to clean the top of the silo for a week's consumption. The silage unloaded for feeding was weighed daily using the feed-mixer.

To calculate the economic benefits of applying the novel covering, the costs of the film used to protect the silo wall and to cover the silo were considered. The average market price of silage was calculated on the basis of the price of the corn grain plus the value of the stover (at a ratio of 45:55) and averaged as $€ 51.5 / \mathrm{t}$ of fresh silage. Labor cost was assumed to be $€ 20 / \mathrm{h}$. All costs were calculated in euros and then converted and reported in tables in US dollars, using an exchange rate of 1.359 .

\section{Sample Preparation and Analyses}

The pre-ensiled material and the silage were each split into 4 subsamples. One subsample was immediately analyzed for DM content by oven drying at $80^{\circ} \mathrm{C}$ for 24 h. The second subsample was dried for qualitative analyses in a forced-draft oven to constant weight at $65^{\circ} \mathrm{C}$, air equilibrated, weighed, and ground in a Cyclotec mill (Tecator, Herndon, VA) to pass a 1-mm screen. This sample was analyzed for $\mathrm{CP}$ (total nitrogen $\times 6.25$ ) by combustion (Micro-N nitrogen analyzer; Elementar Analysensysteme GmbH, Hanau, Germany), for ash by ignition to $550^{\circ} \mathrm{C}$, for $\mathrm{NDF}$ and $\mathrm{ADF}$ as described by Robertson and Van Soest (1981), for ether extract (EE) by ether extraction, and for starch concentration according to the AOAC International (2005) methods.

The third subsample (about $300 \mathrm{~g}$ ) was extracted as a wet sample, using a Stomacher blender (Seward Ltd., Worthing, UK) for $4 \mathrm{~min}$ in distilled water at a waterto-sample material (fresh weight) ratio of 9:1 or in 0.05 $M \mathrm{H}_{2} \mathrm{SO}_{4}$ at an acid-to-sample material (fresh weight) ratio of 5:1. The ammonia $\left(\mathrm{NH}_{3}-\mathrm{N}\right)$ contents and the $\mathrm{pH}$, determined using a specific electrode, were quantified in the water extract. An aliquot of $40 \mathrm{~mL}$ of silage acid extract was centrifuged at 3,622 $\times g$ for $4 \mathrm{~min}$, and the supernatant was filtered with a $0.20-\mu \mathrm{m}$ syringe filter and used for quantification of lactic and monocarboxylic acids (acetic, propionic, and butyric acids) with an HPLC (Agilent Technologies, Santa Clara, CA; Canale et al., 1984). Ethanol was determined by HPLC coupled to a refractive index detector on an Aminex HPX-87H column (Bio-Rad Laboratories, Richmond, $\mathrm{CA}$ ). The analyses were performed isocratically under the following conditions: mobile phase $0.0025 \mathrm{M} \mathrm{H}_{2} \mathrm{SO}_{4}$, flow rate $0.5 \mathrm{~mL} / \mathrm{min}$, column temperature $37^{\circ} \mathrm{C}$, and injection volume $100 \mu \mathrm{L}$. Duplicate analyses were performed for all determined parameters. The duplicates were averaged and the 4 means (replicated silage bags) were considered as 4 observations in the statistical analysis. The water activity $\left(\mathrm{a}_{\mathrm{w}}\right)$ was measured at $25^{\circ} \mathrm{C}$ using an AquaLab Series 3TE water activity meter (Decagon Devices Inc., Pullman, WA) on a fresh sample at ensiling or at silo opening.

The fourth subsample was used for microbiological analyses. A 30-g sample was transferred into sterile homogenization bags, suspended in $270 \mathrm{~g}$ of peptone salt solution ( $1 \mathrm{~g}$ of bacteriological peptone and $9 \mathrm{~g}$ of sodium chloride per liter), and homogenized for $4 \mathrm{~min}$ in a laboratory Stomacher blender for the microbial counts. Serial dilutions were prepared and the colonyforming units of yeasts and molds were counted using the pour-plate technique with $40.0 \mathrm{~g} / \mathrm{L}$ of yeast extract-glucose-chloramphenicol agar (Difco, West Molesey, Surrey, UK) after incubation at $25^{\circ} \mathrm{C}$ for 3 and $5 \mathrm{~d}$ for yeasts and molds, respectively. Mold and yeast counts were enumerated separately according to their macromorphological features. The anaerobic spores were counted after pasteurization of the serial dilutions at $80^{\circ} \mathrm{C}$ for $10 \mathrm{~min}$, followed by the streak plate tech- 
nique with reinforced clostridium medium agar (Oxoid CM149, Oxoid Ltd., Basingstoke, UK), 0.005\% neutral red (Sigma N-7005, Sigma-Aldrich Co., St. Louis, MO), and $200 \mathrm{mg} / \mathrm{kg}$ D-cycloserine (Sigma C-6880) and incubated at $37^{\circ} \mathrm{C}$ for $7 \mathrm{~d}$ in anaerobic jars (Gas-Pak jar BBL Microbiology System, Cockeysville, MD). Aerobic spores were analyzed after pasteurization at $80^{\circ} \mathrm{C}$ for $10 \mathrm{~min}$, followed by double-layer pour-plating with 24.0 g/L nutrient agar (Oxoid CM3). Plates were incubated at $30^{\circ} \mathrm{C}$ for $3 \mathrm{~d}$ and counted. Medium consisting of de Man, Rogosa and Sharpe agar (CM361B, Oxoid), with $0.1 \mathrm{~g} / \mathrm{L}$ of natamycin to prevent fungal growth (Delvocid Instant E-235, DSM, Delft, the Netherlands), was used for enumeration of lactic acid bacteria, after incubation in an anaerobic jar at $30^{\circ} \mathrm{C}$ for $3 \mathrm{~d}$. The mean count of the duplicated subsamples was recorded for all the microbial counts on plates that yielded 1 to 100 cfu per Petri dish.

The DM losses were calculated as the difference between the amount of DM placed in each bag at ensiling and the DM removed at the end of conservation. Characteristics of the 2 plastic sheets were measured as follows: thickness was measured by using a digital electronic micrometer (Digimatic Micrometer MDClite series 293, Mytutoyo Corp., Kamagawa, Japan); oxygen permeability was measured according to the American Society for Testing Materials (ASTM) Standard method D 3985-81 (ASTM, 1980); force was measured at break $(\mathrm{N})$ and energy to break $(\mathrm{J})$, according to the ASTM Standard method F1306-90 (ASTM, 1994; Shimadzu Autograph AGS-H, Shimadzu, Tokyo, Japan; penetration speed: $25 \mathrm{~mm} / \mathrm{min}$; at $23^{\circ} \mathrm{C}$ and $50 \%$ relative humidity); elongation at break in both the machine and transverse directions (Shimadzu Autograph AGS-H; $15 \mathrm{~mm}$ width, $100 \mathrm{~mm} / \mathrm{min}$ at $23^{\circ} \mathrm{C}$ and $50 \%$ relative humidity), according to the International Organization for Standardization standard method 527-1 (ISO, 1993).

\section{Statistical Analysis}

Yeast and mold counts were $\log _{10}$-transformed to obtain log-normal distributed data. The chemical compositional data and microbial counts were analyzed for their statistical significance via ANOVA, with their significance reported at a 0.05 probability level using the general linear model of SPSS software (version 17.0, SPSS Inc., Chicago, IL). The fermentation, microbiological, and nutritional characteristics of the silage at the top of the silo $(\mathrm{n}=32$, for each farm bunker) were analyzed by ANOVA with sealing treatment, distance from the silo wall, and farm (i.e., effect of silo capacity and management) as fixed factors, with 8 replicates. The pooled data of DM losses, ash, starch content, and anaerobic spore count, collected from silages at the top of the silo and in the core from the 2 farms $(\mathrm{n}=72)$, were regressed on mold count as the independent variable. Linear and quadratic regressions were compared using the stepwise selection procedure of the SPSS to select the best regression model at $P<0.05$. The best equation was selected using the coefficient of determination and root mean square error. All reported coefficients of determination $\left(\mathrm{R}^{2}\right)$ were adjusted for degrees of freedom.

\section{RESULTS}

The 2 plastic films differed in oxygen permeability and mechanical characteristics, as reported in Table 1. The HOB film had an oxygen permeability that was only $1.04 \%$ of that of the commercial $200-\mu \mathrm{m}$-thick $\mathrm{PE}$ film. Mechanical characteristics of the 2 films were similar, with higher force at break and elongation at break values in the machine direction and a lower elongation at break value in the transverse direction for the HOB film than the PE film.

The characteristics of the bunker silos used in the 2 trials are reported in Table 2. The 2 farms, which reared 70 and 220 Italian Holsteins milking cows that consumed around $25 \mathrm{~kg} / \mathrm{d} \times$ cow of corn silage, were representative of the intensive dairy farming system of northern Italy. The farms were characterized by a good level of silage management (e.g., silage compaction, plastic film on the silo wall) but different feedout rates, which can influence the likelihood of aerobic deterioration of the silage mass in the peripheral areas. The daily feedout rate differed on the 2 farms because of the differing silo sizes and daily consumption. Apart from gravel bags placed near the side-wall, nothing was used to weigh down the plastic cover on farm 1 , whereas old car tires, distributed uniformly over the top of the silo, were used on farm 2.

Chemical and microbial characteristics of the herbage before ensiling are reported in Table 3. The DM contents at ensiling were similar on the 2 farms and typical of corn harvested at the half milk-line stage.

Table 1. Characteristics of the films studied in the trials ${ }^{1}$

\begin{tabular}{lcc}
\hline Characteristic $^{2}$ & PE & HOB \\
\hline Nominal thickness $(\mu \mathrm{m})$ & 200 & 130 \\
Measured thickness $(\mu \mathrm{m})$ & 198 & 130 \\
Oxygen permeability $\left(\mathrm{cm}^{3} / \mathrm{m}^{2}\right.$ per $\left.24 \mathrm{~h}\right)$ & 846 & 8.8 \\
Force at break $(\mathrm{N})$ & 16 & 21 \\
Energy to break $(\mathrm{J})$ & 0.14 & 0.14 \\
Elongation at break: MD (\%) & 601 & 1,113 \\
Elongation at break: TD (\%) & 1,381 & 1,176 \\
\hline
\end{tabular}

${ }^{1} \mathrm{PE}=$ standard polyethylene film; $\mathrm{HOB}=$ high oxygen barrier film. ${ }^{2}$ Oxygen permeability measured at $23^{\circ} \mathrm{C}$ at $100 \mathrm{kPa}$ and $65 \%$ relative humidity; $\mathrm{MD}=$ machine direction; $\mathrm{TD}=$ transverse direction. 
Table 2. Characteristics of the bunker silos utilized in the 2 trials

\begin{tabular}{lcc}
\hline Item & Farm 1 & Farm 2 \\
\hline Period of consumption & Spring & Spring-Summer \\
Consumption $(\mathrm{t}$ of fresh matter/d) & 2.45 & 6.00 \\
Silo size $(\mathrm{m})$ & 8 & 10 \\
Width & 2.6 & 4.7 \\
Height & 19 & 60 \\
Length & 134 & 186 \\
Days of conservation before silo opening & 66 & 258 \\
Total feedout time $(\mathrm{d})$ & Untreated & Untreated \\
Additive & 1.92 & 1.49 \\
Feedout rate $(\mathrm{m} / \mathrm{wk})$ & 657 & 723 \\
Wet bulk density $\left(\mathrm{kg} / \mathrm{m}^{3}\right)$ & 230 & 260 \\
DM density $\left(\mathrm{kg} / \mathrm{m}^{3}\right)$ & \multicolumn{2}{c}{} \\
\hline
\end{tabular}

The $\mathrm{pH}$, buffering capacity, and water activity were similar in the 2 corn herbages. The starch content on farm 1 was numerically lower than that on farm 2 , and NDF was consequently numerically greater in the corn silage on farm 1 . The yeast and mold counts were $>6$ $\log _{10} \mathrm{cfu} / \mathrm{g}$ of herbage on both farms.

The chemical and fermentative characteristics of the silage cores of the 2 silos are given in Table 4 . Silages were well preserved with a $\mathrm{pH}$ of 3.61 on both farms, and the main fermentative acids were lactic and acetic acids; no butyric acid was found. The fermentation profiles, the lactic:acetic ratio $>6$, and only trace amounts of 1,2-propanediol indicate a dominant homolactic fermentation in both silages. On farm 1, propionic acid was present at $0.25 \%$ of DM and ethanol at $1.09 \%$ of DM. Silages showed a great reduction in yeasts and molds compared with counts at harvest, with yeast and mold counts $<3.0 \log _{10} \mathrm{cfu} / \mathrm{g}$ of silage in both silages. Dry matter losses were $<4 \%$ on both farms and typical of homolactic fermentation in strictly anaerobic silage, whereas aerobic stability was different on the 2 farms, being $<100 \mathrm{~h}$ on farm 1 and $>200$ h on farm 2 .
Chemical, fermentation, and microbiological characteristics of the silage conserved in the peripheral area at 2 distances from the wall and sealed with HOB or PE film for the 2 farms are reported in Table 5 . The use of the HOB film and distance from the silo wall affected almost all measured variables, except for butyric acid, propionic acid, and $\mathrm{NH}_{3}-\mathrm{N}$ contents. The $\mathrm{pH}$ was altered below the PE film and was higher than the $\mathrm{pH}$ of the relative silage conserved under the HOB film. Lactic acid, acetic acid, ethanol, and 1,2-pronanediol contents were greater below the $\mathrm{HOB}$ film than below the $\mathrm{PE}$ film. The yeast and mold counts and the presence of aerobic and anaerobic spore-formers were greater below the PE film than below the HOB film, whereas aerobic stability of silage was greater below the HOB film and was close to $0 \mathrm{~h}$ below the PE film, except for FW silage on farm 2. Dry matter losses were greater below the PE film with values exceeding 50\% DM in the areas close to the silo wall. The HOB film limited losses to $<5 \%$ on farm 1 and $<8 \%$ in the $\mathrm{FW}$ silage of farm 2 . Starch was lower, whereas CP, NDF, ADF, and ash contents were greater under PE than HOB film, except for $\mathrm{FW}$ silage under the PE in farm 2.

Table 3. Chemical and microbiological characteristics of the herbage before ensiling

\begin{tabular}{lcc}
\hline Item & Farm 1 & Farm 2 \\
\hline $\mathrm{DM}(\%)$ & $36.8 \pm 0.441$ & $35.6 \pm 0.788$ \\
$\mathrm{pH}$ & $5.65 \pm 0.123$ & $5.77 \pm 0.055$ \\
Water activity & $0.978 \pm 0.001$ & $0.988 \pm 0.001$ \\
Buffering capacity $(\mathrm{mEq} / \mathrm{kg}$ of DM) & $99.8 \pm 3.10$ & $89.7 \pm 2.56$ \\
$\mathrm{NH}_{3}$-N (\% of DM) & $0.008 \pm 0.001$ & $0.004 \pm 0.001$ \\
$\mathrm{NH}_{3}$-N (\% of total N) & $0.089 \pm 0.006$ & $0.038 \pm 0.008$ \\
$\mathrm{NDF}(\%$ of DM) & $40.1 \pm 1.04$ & $37.6 \pm 0.295$ \\
$\mathrm{ADF} \%$ of DM) & $18.7 \pm 0.454$ & $19.3 \pm 0.289$ \\
$\mathrm{CP}(\%$ of DM) & $6.6 \pm 0.426$ & $6.7 \pm 0.042$ \\
Ether extract $(\%$ of DM) & $2.54 \pm 0.096$ & $2.49 \pm 0.118$ \\
Ash $(\%$ of DM) & $3.26 \pm 0.095$ & $3.14 \pm 0.217$ \\
Starch $(\%$ of DM) & $31.7 \pm 0.873$ & $34.5 \pm 0.496$ \\
Lactic acid bacteria $\left(\log _{10} \mathrm{cfu} / \mathrm{g}\right)$ & $7.38 \pm 0.128$ & $9.35 \pm 0.037$ \\
Yeasts (log $\mathrm{cfu} / \mathrm{g})$ & $6.90 \pm 0.088$ & $6.37 \pm 0.147$ \\
Molds (log $\mathrm{cfu} / \mathrm{g})$ & $6.40 \pm 0.105$ & $6.07 \pm 0.093$ \\
Aerobic spore-formers $\left(\log _{10} \mathrm{cfu} / \mathrm{g}\right)$ & $4.40 \pm 0.098$ & $3.58 \pm 0.328$ \\
Anaerobic spore-formers $\left(\log _{10} \mathrm{cfu} / \mathrm{g}\right)$ & $3.22 \pm 0.145$ & $2.32 \pm 0.382$ \\
\hline
\end{tabular}


Table 4. Chemical and fermentative characteristics of the silages in the core of the 2 bunkers

\begin{tabular}{|c|c|c|}
\hline Item $^{1}$ & Farm 1 & Farm 2 \\
\hline DM (\%) & $36.7 \pm 0.395$ & $35.4 \pm 0.630$ \\
\hline $\mathrm{pH}$ & $3.61 \pm 0.027$ & $3.61 \pm 0.016$ \\
\hline Water activity & $0.977 \pm 0.001$ & $0.986 \pm 0.002$ \\
\hline Lactic acid (\% of DM) & $7.99 \pm 0.339$ & $7.20 \pm 0.833$ \\
\hline Acetic acid (\% of DM) & $1.06 \pm 0.092$ & $1.20 \pm 0.053$ \\
\hline Butyric acid (\% of DM) & $<0.01$ & $<0.01$ \\
\hline Propionic acid (\% of DM) & $0.25 \pm 0.021$ & $0.04 \pm 0.025$ \\
\hline 1,2-Propanediol (\% of DM) & $0.05 \pm 0.033$ & $0.04 \pm 0.044$ \\
\hline Ethanol (\% of DM) & $1.09 \pm 0.034$ & $0.53 \pm 0.023$ \\
\hline Lactic:acetic acid ratio & $7.7 \pm 0.692$ & $6.1 \pm 0.636$ \\
\hline $\mathrm{NH}_{3}-\mathrm{N}(\%$ of $\mathrm{DM})$ & $0.119 \pm 0.010$ & $0.116 \pm 0.004$ \\
\hline $\mathrm{NH}_{3}-\mathrm{N}(\%$ of total $\mathrm{N})$ & $9.74 \pm 1.02$ & $10.57 \pm 0.460$ \\
\hline Yeasts $\left(\log _{10} \mathrm{cfu} / \mathrm{g}\right)$ & $2.71 \pm 0.296$ & $<1.00$ \\
\hline Molds ( $\left.\log _{10} \mathrm{cfu} / \mathrm{g}\right)$ & $2.68 \pm 0.142$ & $2.59 \pm 0.245$ \\
\hline Aerobic spore-formers $\left(\log _{10} \mathrm{cfu} / \mathrm{g}\right)$ & $2.79 \pm 0.135$ & $3.88 \pm 0.232$ \\
\hline Anaerobic spore-formers $\left(\log _{10} \mathrm{cfu} / \mathrm{g}\right)$ & $3.17 \pm 0.165$ & $2.50 \pm 0.666$ \\
\hline Aerobic stability $(\mathrm{h})$ & $75 \pm 8.22$ & $211 \pm 21.7$ \\
\hline DM loss (\%) & $3.1 \pm 0.125$ & $3.8 \pm 0.918$ \\
\hline $\mathrm{CP}(\%$ of $\mathrm{DM})$ & $7.0 \pm 0.096$ & $6.7 \pm 0.309$ \\
\hline Starch (\% of DM) & $34.4 \pm 0.158$ & $37.9 \pm 0.527$ \\
\hline $\mathrm{NDF}(\%$ of DM) & $39.8 \pm 0.539$ & $36.0 \pm 0.334$ \\
\hline $\mathrm{ADF}(\%$ of $\mathrm{DM})$ & $19.1 \pm 1.05$ & $19.3 \pm 0.671$ \\
\hline Ether extract (\% of DM) & $2.95 \pm 0.354$ & $3.01 \pm 0.060$ \\
\hline Ash $(\%$ of DM) & $3.30 \pm 0.314$ & $3.16 \pm 0.210$ \\
\hline
\end{tabular}

Mold count was closely and positively correlated with the DM losses, ash content, and anaerobic sporeformers, and was negatively correlated with the starch content (Figures 1 to 4 ). When the mold content exceeded $5 \log _{10} \mathrm{cfu} / \mathrm{g}$ of silage, DM losses were $>12 \%$, and when mold counts increased beyond $6 \log _{10} \mathrm{cfu} / \mathrm{g}$ of silage, DM losses exceeded $40 \%$ of the original DM . The starch content of the silage began to decrease when the mold count increased to $>5 \log _{10} \mathrm{cfu} / \mathrm{g}$ of silage and fell below $10 \%$ of DM when the mold count was $>7$ $\log _{10} \mathrm{cfu} / \mathrm{g}$ of silage. Anaerobic spore-formers increased over $5 \log _{10} \mathrm{cfu} / \mathrm{g}$ when the mold count increased to $>4$ $\log _{10} \mathrm{cfu} / \mathrm{g}$ of silage.

The effects of silo management on the 2 farms on DM and economic losses due to silo coverage are reported in Table 6. The plastic coverage affected the amount of discarded silage on both farms, with economic losses due to both the inedible silage that had to be discarded and the labor needed to discard it. Considering the difference between the greater cost of the HOB plastic film and the lower costs due to the lower amount of silage discarded and the lower labor cost to discard spoiled silage, a net benefit resulted from the use of the HOB film of $\$ 307$ and $\$ 821$ per half silo, for farms 1 and 2 , respectively.

\section{DISCUSSION}

The importance of uniform high-quality silage over the whole profile of the silo has recently been stated by several researchers (Muck, 2013; Wilkinson and Davies, 2013). In farm conditions, improper incorporation of deteriorated parts from the top layers of the silo in the feed-mixer could increase the final feed contamination by undesirable microorganisms, such as filamentous fungi and aerobic and anaerobic spores (Borreani et al., 2013; Dunière et al., 2013), and harmful mycotoxins (Cavallarin et al., 2011; , Cheli et al., 2013), and could reduce DM intake (Gerlach et al., 2013) and dairy cow performance (Tabacco et al., 2011b; Queiroz et al. 2012). Good microbiological quality throughout the whole silo face could be obtained by increasing silage density through compaction during filling of the silo (Muck and Holmes, 2000), by planning the silo size to obtain a correct daily feedout rate depending on the season and latitude (Borreani and Tabacco, 2012b), by properly sealing and covering the silo to avoid oxygen penetration during the conservation phase (Borreani et al., 2007; Bernardes et al., 2012), by using a Lactobacillus buchneri-based inoculant to address silage fermentation and increase aerobic stability of the silage (Mari et al., 2009; Kristensen et al., 2010; Tabacco et al., 2011a), by weighing down the cover to hold it tightly in place and maintain contact between the plastic film and the silage (McDonell and Kung, 2006), and by reducing the risk of mechanical damage to the cover by protecting it with a net or tarpaulin sheet. One of the most effective ways of reducing top spoilage is to reduce oxygen penetration in the silage mass during conservation and feedout phase. This goal could be achieved by using 
Table 5. Fermentative characteristics, microbial counts, and aerobic stability of silages at opening in relation to film used to seal silage, distance from the silo wall, and silo size and management (farm 1 and farm 2$)^{1}$

\begin{tabular}{|c|c|c|c|c|c|c|c|c|c|c|c|c|c|c|c|}
\hline \multirow[b]{3}{*}{ Item } & \multicolumn{4}{|c|}{ Farm 1} & \multicolumn{4}{|c|}{ Farm 2} & \multicolumn{6}{|c|}{ Effect ( $P$-value $)$} & \multirow[b]{3}{*}{$\mathrm{SE}$} \\
\hline & \multicolumn{2}{|c|}{$\mathrm{PE}$} & \multicolumn{2}{|c|}{$\mathrm{HOB}$} & \multicolumn{2}{|c|}{$\mathrm{PE}$} & \multicolumn{2}{|c|}{$\mathrm{HOB}$} & \multirow[b]{2}{*}{$\underset{(F)}{\text { Film }}$} & \multirow[b]{2}{*}{$\begin{array}{l}\text { Distance } \\
\text { (D) }\end{array}$} & \multirow[b]{2}{*}{$\begin{array}{l}\text { Silo size } \\
(\mathrm{S})^{2}\end{array}$} & \multirow[b]{2}{*}{$\mathrm{F} \times \mathrm{D}$} & \multirow[b]{2}{*}{$\mathrm{F} \times \mathrm{S}$} & \multirow[b]{2}{*}{$\mathrm{D} \times \mathrm{S}$} & \\
\hline & $\mathrm{CW}$ & FW & $\mathrm{CW}$ & FW & $\mathrm{CW}$ & $\mathrm{FW}$ & $\mathrm{CW}$ & FW & & & & & & & \\
\hline $\mathrm{DM}(\%)$ & 20.7 & 28.0 & 35.6 & 36.0 & 14.1 & 31.7 & 28.2 & 34.3 & $* * *$ & $* * *$ & NS & * & NS & * & 1.527 \\
\hline Water activity & 0.992 & 0.984 & 0.983 & 0.983 & 0.992 & 0.983 & 0.984 & 0.982 & * & $* *$ & NS & * & NS & NS & 0.001 \\
\hline $\mathrm{pH}$ & 6.62 & 5.85 & 3.78 & 3.79 & 7.27 & 3.96 & 4.64 & 3.94 & $* * *$ & ** & NS & * & NS & * & 0.287 \\
\hline Lactic acid (\% of DM) & 0.65 & 0.73 & 3.24 & 3.21 & 0.03 & 2.95 & 2.26 & 2.74 & $* * *$ & $* *$ & NS & * & * & $* *$ & 0.252 \\
\hline Acetic acid (\% of DM) & 0.40 & 0.63 & 1.90 & 1.94 & 0.45 & 3.57 & 3.55 & 3.58 & $* * *$ & $*$ & $* * *$ & $*$ & NS & $*$ & 0.282 \\
\hline Butyric acid (\% of DM) & 0.07 & 0.13 & $<0.01$ & $<0.01$ & 0.20 & $<0.01$ & 0.04 & 0.08 & NS & NS & NS & NS & NS & NS & 0.029 \\
\hline Propionic acid (\% of DM) & 0.12 & 0.20 & 0.20 & 0.21 & 0.04 & 1.04 & 0.65 & 0.35 & NS & NS & * & * & NS & NS & 0.083 \\
\hline 1,2-Propanediol ( $\%$ of DM) & $<0.01$ & $<0.01$ & 0.07 & 0.17 & $<0.01$ & 0.05 & 0.41 & 0.12 & $* * *$ & NS & NS & NS & NS & NS & 0.029 \\
\hline Ethanol (\% of DM) & 0.03 & 0.13 & 0.70 & 0.60 & $<0.01$ & 0.58 & 0.30 & 0.64 & $* * *$ & $* *$ & NS & NS & $* *$ & $* *$ & 0.057 \\
\hline $\mathrm{NH}_{3}-\mathrm{N}(\%$ of $\mathrm{DM})$ & 0.136 & 0.077 & 0.093 & 0.072 & 0.35 & 0.11 & 0.16 & 0.11 & NS & NS & NS & NS & NS & NS & 0.028 \\
\hline $\mathrm{NH}_{3}-\mathrm{N}(\%$ of total $\mathrm{N})$ & 5.61 & 4.09 & 8.08 & 6.12 & 12.61 & 10.13 & 10.09 & 9.78 & NS & NS & * & NS & NS & NS & 1.042 \\
\hline Yeast $\left(\log _{10} \mathrm{cfu} / \mathrm{g}\right)$ & 7.03 & 5.26 & 2.34 & 3.14 & 5.32 & 2.30 & 1.27 & 1.21 & $* * *$ & $*$ & $* * *$ & $* *$ & NS & NS & 0.411 \\
\hline Mold $\left(\log _{10} \mathrm{cfu} / \mathrm{g}\right)$ & 7.27 & 6.16 & 2.24 & 2.13 & 7.36 & 3.32 & 5.17 & 2.63 & $* * *$ & *** & NS & NS & $* * *$ & $* *$ & 0.403 \\
\hline Aerobic spore-formers $\left(\log _{10} \mathrm{cfu} / \mathrm{g}\right)$ & 7.65 & 6.62 & 2.49 & 2.48 & 7.91 & 3.41 & 5.76 & 2.79 & $* * *$ & $* * *$ & NS & NS & $* *$ & $* *$ & 0.455 \\
\hline Anaerobic spore-formers $\left(\log _{10} \mathrm{cfu} / \mathrm{g}\right)$ & 8.20 & 7.26 & 3.38 & 3.36 & 7.50 & 4.73 & 6.20 & 3.72 & $* * *$ & $* *$ & NS & NS & $* *$ & $* *$ & 0.360 \\
\hline DM loss $(\%)$ & 55.3 & 33.6 & 3.0 & 4.2 & 66.4 & 10.5 & 28.6 & 7.5 & $* * *$ & $* * *$ & NS & $* *$ & * & ** & 4.49 \\
\hline Aerobic stability (h) & 0 & 0 & 107 & 70 & 0 & 57 & 12 & 83 & $* *$ & NS & NS & NS & $*$ & $*$ & 9.85 \\
\hline $\mathrm{CP}(\%$ of $\mathrm{DM})$ & 15.0 & 12.1 & 7.4 & 7.4 & 15.7 & 6.8 & 9.4 & 6.6 & $* * *$ & $* * *$ & NS & $* *$ & NS & $*$ & 0.716 \\
\hline Starch (\% of DM) & 8.2 & 17.2 & 34.1 & 32.9 & 1.9 & 40.9 & 20.3 & 41.4 & $* * *$ & $* * *$ & NS & $*$ & NS & $* * *$ & 2.79 \\
\hline $\mathrm{NDF}(\%$ of $\mathrm{DM})$ & 56.2 & 51.9 & 41.5 & 42.6 & 58.6 & 40.0 & 50.5 & 38.6 & $* * *$ & $* * *$ & NS & NS & $*$ & $* * *$ & 1.47 \\
\hline $\operatorname{ADF}(\%$ of $\mathrm{DM})$ & 43.0 & 31.5 & 20.4 & 20.6 & 40.5 & 22.0 & 29.7 & 21.2 & $* * *$ & $* * *$ & NS & $* *$ & $* *$ & $* * *$ & 1.66 \\
\hline Ether extract (\% of DM) & 3.92 & 3.55 & 2.87 & 2.90 & 3.56 & 2.79 & 3.68 & 3.03 & $*$ & $* *$ & NS & NS & $* *$ & NS & 0.094 \\
\hline Ash $(\%$ of DM) & 7.88 & 6.60 & 3.37 & 3.38 & 12.23 & 4.76 & 6.55 & 4.24 & $* * *$ & $* * *$ & $*$ & * & NS & $* *$ & 0.578 \\
\hline
\end{tabular}

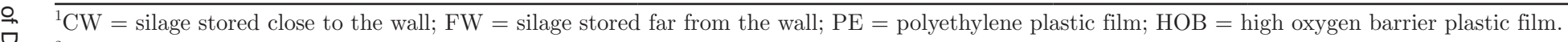

$\stackrel{2}{2}$ Silo size accounts for the effects of silo capacity and silo management (i.e., farm 1 vs. farm 2 ).

( $\quad * * * P<0.001 ;{ }^{* *} P<0.01 ;{ }^{*} P<0.05 ; 3$-way interactions $(\mathrm{F} \times \mathrm{D} \times \mathrm{S})$ were always nonsignificant. 


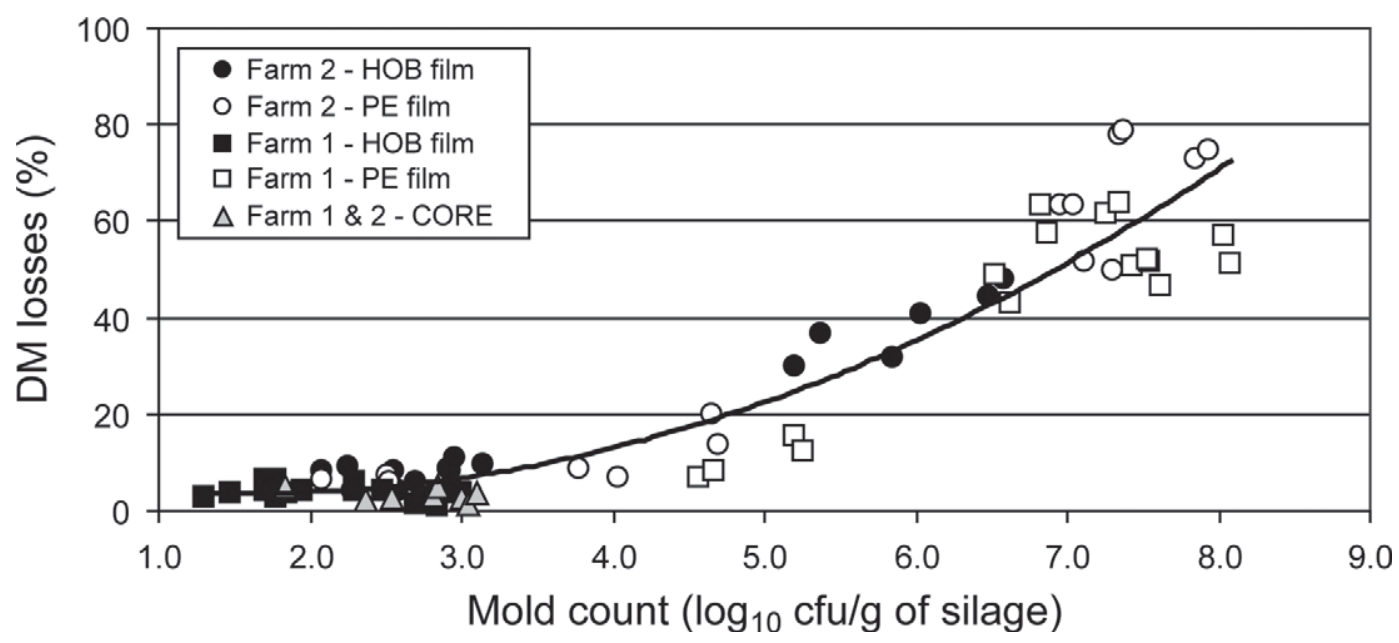

Figure 1. Dry matter losses of corn silages from the 2 silos correlated with the mold count. Regression equation: DM losses (\%) $=1.707$ MOLD_COUNT ${ }^{2}-5.805$ MOLD_COUNT +8.330 , where mold count is expressed as $\log _{10} \mathrm{cfu} / \mathrm{g}$ of silage; $\mathrm{R}^{2}=0.91$. HOB $=$ high oxygen barrier plastic film; $\mathrm{PE}=$ polyethylene plastic film; $\mathrm{CORE}=$ silage sampled in the central mass of the silo in farm 1 and 2.

a high-quality plastic film that, to be effective, must couple enhanced impermeability to oxygen with good mechanical properties.

In this study, the HOB film was made by coextruding a layer of a special grade of EVOH between 2 layers of polyethylene. The EVOH layer improved the oxygen impermeability of the HOB film by about 10 -fold compared with the first generation of OB films. These first-generation $\mathrm{OB}$ films were made by coextruding polyethylene and PA, and were reported by Borreani et al. (2007) to have oxygen permeability of $100 \mathrm{~cm}^{3} /$ $\mathrm{m}^{2}$ (in $24 \mathrm{~h}$ at $23^{\circ} \mathrm{C}, 100 \mathrm{kPa}$, and $85 \%$ relative humidity). The mechanical characteristics of the coextruded HOB film were similar to those of the PE film and im- proved notably compared with OB films (De Angelis, 2012). This is due to the new EVOH formula, which is particularly soft at ambient temperature, and to the reduced thickness of the EVOH layer, which is about one-sixth of the thickness of the PA layer used to made the first generation of OB films (Borreani et al., 2007).

In the present study, the increased oxygen impermeability of the HOB film used to cover the silage greatly improved the microbial and fermentation quality of the corn silage stored in the top layer of the silo on both farms compared with the commercial PE film. Silages conserved under the HOB film had a higher lactic acid content, lower $\mathrm{pH}$, and lower counts of yeasts, molds, and aerobic and anaerobic spore-formers, greater

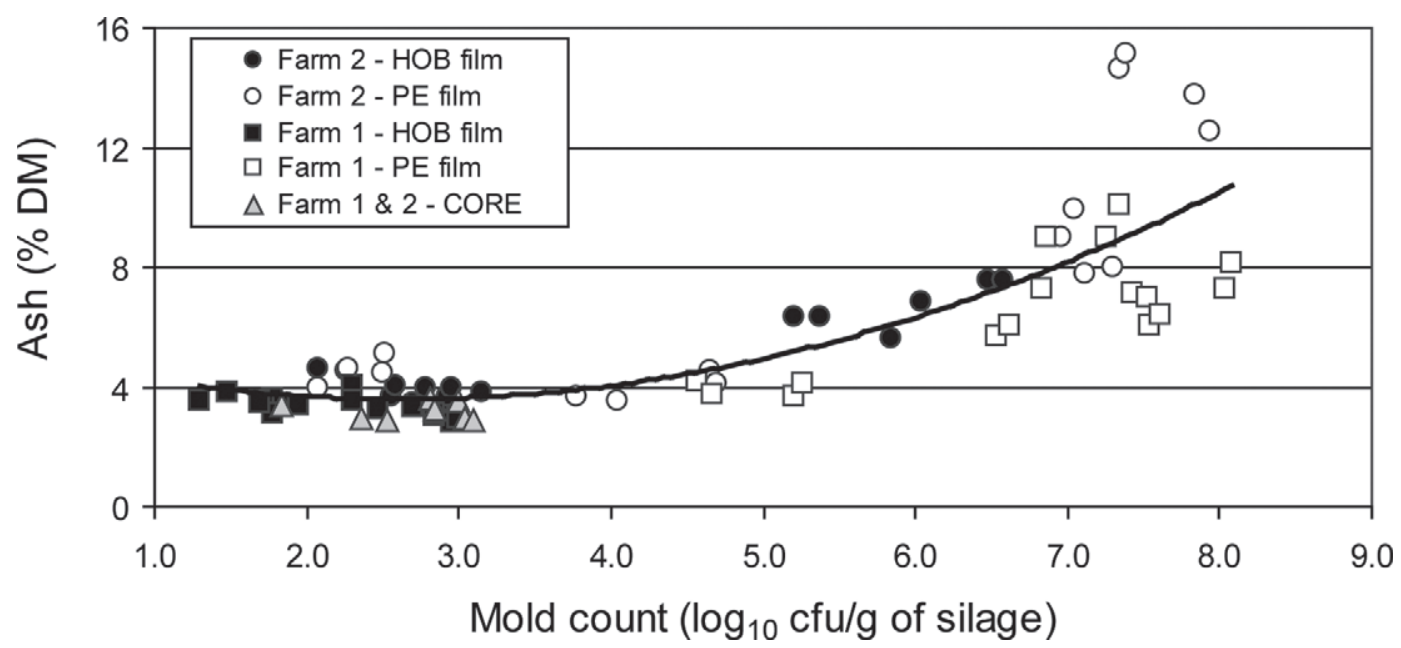

Figure 2. Ash content of corn silages from the 2 silos correlated with the mold count. Regression equation: Ash content $(\%)=0.243 \mathrm{MOLD} \_$ $\mathrm{COUNT}^{2}-1.270$ MOLD_COUNT +5.170 , where mold count is expressed as $\log _{10} \mathrm{cfu} / \mathrm{g}$ of silage; $\mathrm{R}^{2}=0.70$. HOB $=$ high oxygen barrier plastic film; $\mathrm{PE}=$ polyethylene plastic film; CORE $=$ silage sampled in the central mass of the silo in farm 1 and 2. 


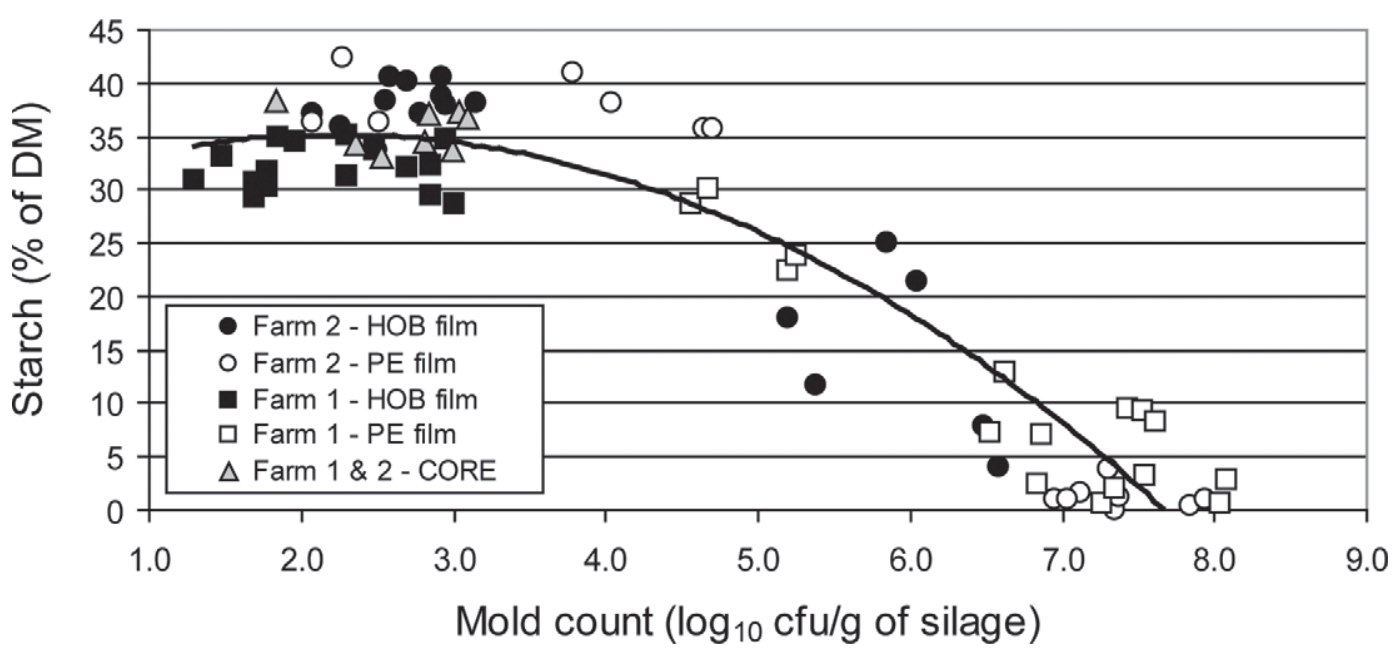

Figure 3. Starch content of corn silages from the 2 silos correlated with the mold count. Regression equation: Starch content $(\%)=-1.187$ MOLD_COUNT ${ }^{2}+5.256$ MOLD_COUNT +29.55 , where mold count is expressed as $\log _{10} \mathrm{cfu} / \mathrm{g}$ of silage; $\mathrm{R}^{2}=0.89$. HOB $=$ high oxygen barrier plastic film; $\mathrm{PE}=$ polyethylene plastic film; $\mathrm{CORE}=$ silage sampled in the central mass of the silo in farm 1 and 2 .

aerobic stability, and lesser DM losses than silages conserved under the PE film. Berger and Bolsen (2006) reported that corn silage covered with an OB film had a lower $\mathrm{pH}$ and higher lactic acid content than corn silage covered with a $200-\mu \mathrm{m}$-thick PE film. A higher lactic acid content and lower $\mathrm{pH}$ in the top layer of corn silage covered with an OB film were also reported by Borreani et al. (2007) and Bernardes et al. (2012). In the present study, the improvement in silage quality due to the HOB film was observed both close to and far from the silo wall. McDonell (2008), comparing silage stored under different covers, reported that the $\mathrm{pH}$ of the silage closest to the wall under a PE film was the highest and it decreased further from the wall, whereas the $\mathrm{pH}$ of silage covered with an OB film was lower and not affected by sampling at various widths. The same author (McDonell, 2008) reported that lactic acid was almost twice as high for silage stored under an OB film as that stored under a PE film. The reduced oxygen availability during conservation had a great effect on the yeast population in the upper $400 \mathrm{~mm}$ of the 2 bunker silos in the current study. The yeast count was markedly lower in the silage stored under the HOB film than in that under the PE film, with values that were similar to or slightly higher than those observed in the core of the silage mass of both farms. Some previous works have reported that the better anaerobic environment under an OB film in laboratory

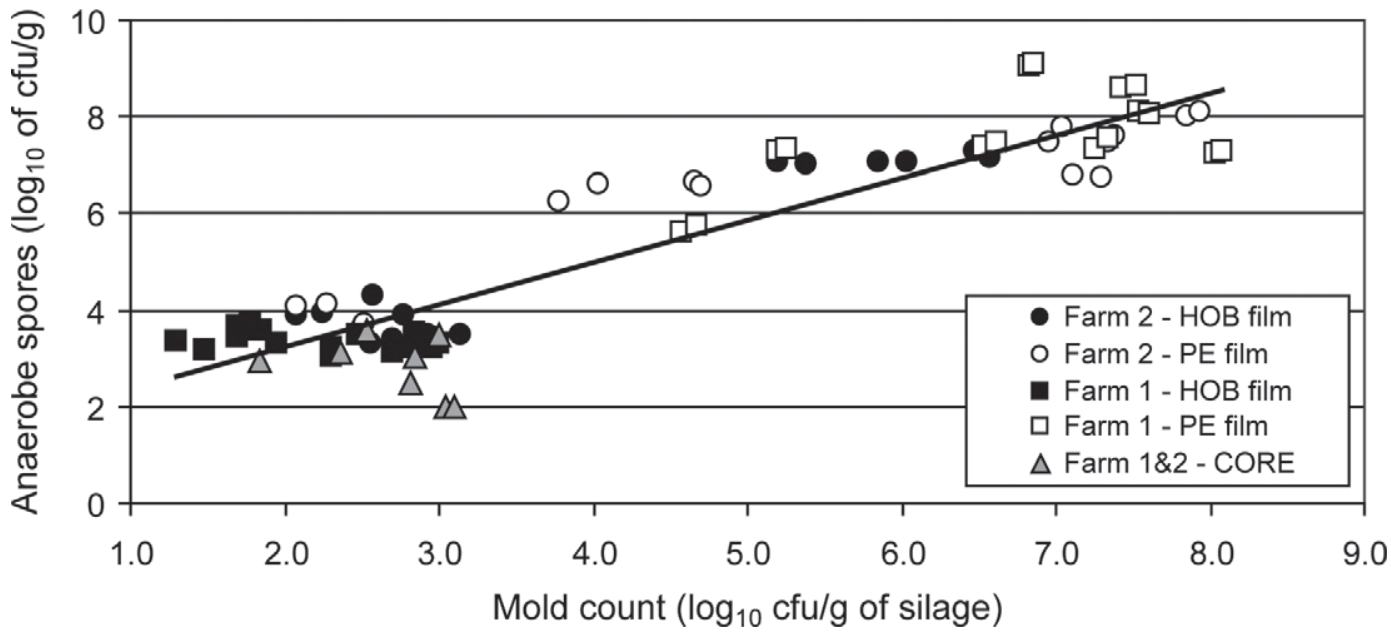

Figure 4. Anaerobic spore count of corn silages from the 2 silos correlated with the mold count. Regression equation: Anaerobic spore (log 10 $\mathrm{cfu} / \mathrm{g})=0.876 \mathrm{MOLD} \_$COUNT +1.476 , where mold count is expressed as $\log _{10} \mathrm{cfu} / \mathrm{g}$ of silage; $\mathrm{R}^{2}=0.85$. HOB $=$ high oxygen barrier plastic film; $\mathrm{PE}=$ polyethylene plastic film; $\mathrm{CORE}=$ silage sampled in the central mass of the silo in farm 1 and 2. 
Table 6. Dry matter and economic losses of the 2 half parts of the silo covered with different plastic films in farms 1 and $2^{1}$

\begin{tabular}{|c|c|c|c|c|}
\hline \multirow[b]{2}{*}{ Item } & \multicolumn{2}{|c|}{ Farm 1} & \multicolumn{2}{|c|}{ Farm 2} \\
\hline & $\mathrm{PE}$ & HOB & $\mathrm{PE}$ & HOB \\
\hline Total fresh herbage ensiled $(\mathrm{t})$ & 92.3 & 92.3 & 899.2 & 899.2 \\
\hline \multicolumn{5}{|l|}{ Depth of visible surface mold (m) } \\
\hline from the top & 0.26 & 0.13 & 0.23 & 0.18 \\
\hline from the wall & 2.33 & 0.28 & 1.65 & 0.83 \\
\hline Total spoiled silage discarded (t) & 3.32 & 0.40 & 11.77 & 2.39 \\
\hline Total silage at end of storage period $(\mathrm{t})$ & 80.8 & 84.5 & 806.9 & 817.4 \\
\hline Total silage lost $(\mathrm{t})$ & 10.3 & 6.6 & 80.8 & 70.3 \\
\hline Total silage lost (\% of the crop ensiled) & 11.3 & 7.2 & 9.1 & 7.9 \\
\hline Total value of silage in the silo $(\$)$ & 6,375 & 6,375 & 62,129 & 62,129 \\
\hline Economic loss due to spoiled silage $(\$)$ & 287 & 29 & 920 & 182 \\
\hline Labor to discard spoiled silage $(\mathrm{h})$ & 5.5 & 0.7 & 19.6 & 4.0 \\
\hline Labor cost $(\$)$ & 151 & 18 & 533 & 109 \\
\hline Cost of plastic cover ${ }^{2}(\$)$ & 65 & 149 & 266 & 609 \\
\hline Net benefit from HOB film $(\$)$ & & 307 & & 821 \\
\hline Net benefit from HOB film ( $\$ / \mathrm{t}$ ensiled $)$ & & 3.33 & & 0.91 \\
\hline
\end{tabular}

silos contributed to reducing yeast counts to $<2.0 \log _{10}$ cfu/g of silage (Dolci et al., 2011) and consequently to increasing the aerobic stability of silages when exposed to air. McDonell (2008) also found a lower yeast count in corn ensiled in laboratory silos and covered with an OB film (45 $\mu \mathrm{m}$ thick) compared with a PE film (150 $\mu \mathrm{m}$ thick). In the present paper, the greater number of yeasts in the silage conserved under the PE film made the silage less aerobically stable so that, when air had access to the silo during the feedout phase, aerobic deterioration was faster in this part of the bunker than in the part covered with the HOB film, on both farms. The evidence of increased shelf life of silage after exposure to air, due to the use of an oxygen barrier film, was previously reported for laboratory silos (Dolci et al., 2011) and farm-scale silos (Borreani et al., 2007; Orosz et al., 2013). Borreani et al. (2007) and Orosz et al. (2013) reported that corn silage in the upper layer under an OB film had a lower yeast count and greater aerobic stability than silage stored under a conventional polyethylene film. Increased aerobic stability and a lower yeast count in the upper layer of silage, stored under an OB film, have been attributed to reduced oxygen permeation through the silo seal during the storage period (Wilkinson and Davies, 2013). In our experiment, the delay in onset of aerobic deterioration in the silage under the HOB film resulted in lower DM losses and a lesser amount of spoiled silage that had to be discarded at the time of silo consumption to avoid critical contamination of the ration in the feed-mixer. This led to a net gain when the HOB film was used on both studied farms, due to the increased DM recovery and reduced labor time required to clean the top layer daily. The economic return when the HOB film was used instead of a standard PE film was inversely related to the amount of DM ensiled and was $\$ 3.33$ and $\$ 0.91 / \mathrm{t}$ of fresh matter ensiled, on farms 1 and 2 , respectively. These results are slightly lower than those reported by Bolsen et al. (1993), who estimated the economic benefit of 2 sealing methods (standard polyethylene and OB films) and calculated that the use of an OB film to cover silage would save more than $\$ 5 / \mathrm{t}$ of ensiled DM compared with a standard polyethylene cover. In the present experiment, when all data from the 2 farms and the 2 sealing covers were pooled, we found a close relationship between the mold count and chemical and fermentative quality of the silage: as the mold count in the silage increased, the DM losses and the ash content increased, whereas the starch content decreased exponentially. It is clear that the use of the HOB film protected almost all the silage in the top layer from spoiling, because only 6 out of 32 samples had a mold count $>3 \log _{10} \mathrm{cfu} / \mathrm{g}$, and only 2 had a mold count $>6 \log _{10} \mathrm{cfu} / \mathrm{g}$. When feeding contaminated silage to milking dairy cows or young cows, the general recommendations are that silages with $\leq 4 \log _{10} \mathrm{cfu} / \mathrm{g}$ are generally safe, whereas silage with a mold count $>6$ $\log _{10} \mathrm{cfu} / \mathrm{g}$ should be discarded (Mahanna and Chase, 2003). This is the case in our experiment for most of the silage samples (20 out of 32 ) from the parts of the bunkers that were covered with the commercial PE film. These samples lost from 40 to $80 \%$ of the original $\mathrm{DM}$, and all the lactic acid and almost all the starch were depleted due to activity of yeasts and molds.

The risk of aerobic and anaerobic spore-former outgrowth in the peripheral areas of the silo was greatly reduced through utilization of the HOB film. This result is in agreement with results obtained with the 
OB film at both the farm level (Borreani and Tabacco, 2008) and in laboratory silos (Borreani et al., 2013). Furthermore, in the present experiment, the anaerobic spore count, which is linked to the risk of spore milk contamination, increased linearly with an increase in the mold count, emphasizing that inclusion of parts of the silage that were visually spoiled (mold count $>5$ $\log _{10} \mathrm{cfu} / \mathrm{g}$ ) increases the risk of worsening the microbiological status of the TMR fed to lactating dairy cows (Tabacco et al., 2009; Borreani et al., 2013).

\section{CONCLUSIONS}

The quality of the silage throughout the entire silo face was improved by use of the HOB film, and spoiled silage was minimized $(<0.6 \%$ of the silo surface compared with $5.8 \%$ for the part covered with the PE film), especially in the corner areas close to the bunker walls where the DM density was lower and it is more difficult to seal the silos. The HOB film helped to create a more anaerobic environment than the PE film in the upper layer of the silo, reduced the yeast count during conservation, and increased the aerobic stability of the silage. As a consequence, the use of the HOB film ensured a longer shelf life of silage after air gained access to the silo during consumption, by delaying the growth of yeasts, molds, and aerobic and anaerobic spore-formers and by reducing their detrimental effect on the nutritional and microbiological quality of silage in the upper layer of the silo.

\section{ACKNOWLEDGMENTS}

The authors thank Domenico Deangelis (Nippon Gohsei Europe, Düsseldorf, Germany) for the development of the coextruded barrier plastic films used in the experiment; Serenella Piano and Piero Michele Meda (DISAFA, University of Turin, Italy) for the chemical and microbiological analyses; and Pierangelo Franco, Luciano Comino, and Mauro Comino for having made their bunker silos available. This work was funded by the Regione Piemonte, Assessorato Qualità, Ambiente e Agricoltura, 2010 to 2013 project "Miglioramento della qualità nutrizionale e della sicurezza alimentare e microbiologica della filiera lattiero-casearia in Piemonte.," and by MIPAAF, 2011 to 2014 Project: FILIGRANA "Valorizzazione della produzione del Grana Padano DOP tramite il controllo di filiera e l'ottimizzazione dei processi produttivi."

\section{REFERENCES}

AOAC International. 2005. Official Methods of Analysis. 18th ed. AOAC International, Gaithersburg, MD.
Ashbell, G., and N. Lisker. 1988. Aerobic deterioration in maize silage stored in a bunker silos under farm conditions in a subtropical climate. J. Sci. Food Agric. 45:307-315.

Ashbell, G., and Z. G. Weinberg. 1992. Top silage losses in horizontal silos. Can. J. Eng. 34:171-175.

ASTM. 1980. ASTM Standard method D 3985-81. In Annual Book of Standards. American Society for Testing Materials (ASTM), Philadelphia, PA.

ASTM. 1994. ASTM Standard method F 1306-90. Standard test method for slow rate penetration resistance of flexible barrier films and laminates. American Society for Testing Materials (ASTM), Philadelphia, PA.

Berger, L. L., and K. K. Bolsen. 2006. Sealing strategies for bunker silos and drive-over piles. Pages 266-283 in Proc. Silage for Dairy Farms: Growing, Harvesting, Storing, and Feeding. NRAES Publ. 181. Cornell University, Ithaca, NY.

Bernardes, T. F., L. G. Nussio, and R. C. do Amaral. 2012. Top spoilage losses in maize silage sealed with plastic films with different permeabilities to oxygen. Grass Forage Sci. 67:34-42.

Bolsen, K. K., J. T. Dickerson, B. E. Brent, R. N. Sonon Jr., B. S. Dalke, C. Lin, and J. E. Boyer Jr. 1993. Rate and extent of top spoilage losses in horizontal silos. J. Dairy Sci. 76:2940-2962.

Borreani, G., P. Dolci, E. Tabacco, and L. Cocolin. 2013. Aerobic deterioration stimulates outgrowth of spore-forming Paenibacillus in corn silage stored under oxygen-barrier or polyethylene films. J. Dairy Sci. 96:5206-5216.

Borreani, G., and E. Tabacco. 2008. Low permeability to oxygen of a new barrier film prevents outgrowth of butyric acid bacteria in farm corn silage. J. Dairy Sci. 91:4272-4281.

Borreani, G., and E. Tabacco. 2010. The relationship of silage temperature with the microbiological status of the face of corn silage bunkers. J. Dairy Sci. 93:2620-2629.

Borreani, G., and E. Tabacco. 2012a. Special EVOH-based films with lowered oxygen permeability reduce dry matter losses and increase aerobic stability of farm maize silages. Pages 302-303 in Proc. XVI Int. Silage Conf. K. Kuoppala, M. Rinne, and A. Vanhatalo, ed. MTT Agrifood Research Finland, University of Helsinki, Helsinki, Finland.

Borreani, G., and E. Tabacco. 2012b. Effect of silo management factors on aerobic stability and extent of spoilage in farm maize silages. Pages 71-72 in Proc. XVI Int. Silage Conf. K. Kuoppala, M. Rinne, and A. Vanhatalo, ed. MTT Agrifood Research Finland, University of Helsinki, Helsinki, Finland.

Borreani, G., E. Tabacco, and L. Cavallarin. 2007. A new oxygen barrier film reduces aerobic deterioration in farm-scale corn silage. J. Dairy Sci. 90:4701-4706.

Borreani, G., E. Tabacco, and D. Deangelis. 2011. Special EVOHbased films improve quality and sanity of farm corn silage. Pages 1-15 in Proc. Agricultural Film 2011: Int. Conf. Agricultural and Horticultural Film Industry. Applied Market Information Ltd., Barcelona, Spain.

Canale, A., M. E. Valente, and A. Ciotti. 1984. Determination of volatile carboxylic acids $(C 1-C 5)$ and lactic acid in aqueous acid extracts of silage by high performance liquid chromatography. J. Sci. Food Agric. 35:1178-1182.

Cavallarin, L., E. Tabacco, S. Antoniazzi, and G. Borreani. 2011. Aflatoxin accumulation in whole crop maize silage as a result of aerobic exposure. J. Sci. Food Agric. 91:2419-2425.

Cheli, F., A. Campagnoli, and V. Dell'Orto. 2013. Fungal populations and mycotoxins in silages: From occurrence to analysis. Anim. Feed Sci. Technol. 183:1-16.

De Angelis, D. 2012. High barrier resin for all silage applications. Pages 4.21-4.45 in Agricultural Film 2012: Int. Conf. Agric. Horticultural Film Industry. Applied Market Information Ltd., Madrid, Spain.

Dolci, P., E. Tabacco, L. Cocolin, and G. Borreani. 2011. Microbial dynamics during aerobic exposure of corn silage stored under oxygen barrier or polyethylene films. Appl. Environ. Microbiol. 77:7499-7507.

Dunière, L., J. Sindou, F. Chaucheyras-Durand, I. Chevallier, and D. Thévenot-Sergentet. 2013. Silage processing and strategies to pre- 
vent persistence of undesirable microorganisms. Anim. Feed Sci. Technol. 182:1-15.

Gerlach, K., F. Roß, K. Weiß, W. Büscher, and K. H. Südekum. 2013. Changes in maize silage fermentation products during aerobic deterioration and effects on dry matter intake by goats. Agric. Food Sci. 22:168-181.

ISO. 1993. Plastics: Determination of tensile properties. Part 1: General principles. International Organization for Standardization (ISO), Geneva, Switzerland.

Kristensen, N. B., K. H. Sloth, O. Højberg, N. H. Spliid, C. Jensen, and R. Thøgersen. 2010. Effects of microbial inoculants on corn silage fermentation, microbial contents, aerobic stability, and milk production under field conditions. J. Dairy Sci. 93:3764-3774.

Mahanna, B., and L. E. Chase. 2003. Practical applications and solutions to silage problems. Pages $855-895$ in Silage Science and Technology. Vol. 42. D. R. Buxton, R. E. Muck, and J. H. Harrison, ed. Am. Soc. Agron., Crop Sci. Soc. Am., Soil Sci. Soc. Am., Madison, WI.

Mari, L. J., R. J. Schmidt, L. G. Nussio, C. M. Hallada, and L. Kung Jr. 2009. An evaluation of the effectiveness of Lactobacillus buchneri 40788 to alter fermentation and improve the aerobic stability of corn silage in farm silos. J. Dairy Sci. 92:1174-1176.

McDonell, E. E. 2008. An evaluation of methods used to cover bunker silos with oxygen barrier plastic to maintain the nutritive value of silage. PhD Thesis. University of Delaware, Newark.

McDonell, E. E., and L. Kung Jr. 2006. An update on covering bunker silos. University of Delaware, Newark. Accessed Aug. 30, 2013. http:// ag.udel.edu/anfs/faculty/kung/documents/CoveringBunkerSilos_ 000.pdf.

Muck, R. E. 2013. Recent advances in silage microbiology. Agric. Food Sci. 22:3-15.

Muck, R. E., and B. J. Holmes. 2000. Factors affecting bunker silo densities. Appl. Eng. Agric. 16:613-619.

Orosz, S., J. M. Wilkinson, S. Wigley, Z. Bìrò, and J. Gallo. 2013. Microbial status, aerobic stability and fermentation of maize silage sealed with an oxygen barrier film. Agric. Food Sci. 22:182-188.

Queiroz, O. C. M., A. T. Adesogan, K. G. Arriola, and M. F. S. Queiroz. 2012. Effect of a dual-purpose inoculant on the quality and nutrient losses from corn silage produced in farm-scale silos. J. Dairy Sci. 95:3354-3362.

Ranjit, N. K., and L. Kung Jr. 2000. The effect of Lactobacillus buchneri, Lactobacillus plantarum, or a chemical preservative on the fermentation and aerobic stability of corn silage. J. Dairy Sci $83: 526-535$.

Robertson, J. B., and P. J. Van Soest. 1981. The detergent system of analysis and its application to human foods. Pages $123-158$ in The Analysis of Dietary Fiber in Food. W. P. T. James and O. Theander, ed. Marcel Dekker, New York, NY.

Rübbelke, I. 2012. Technology trends and requirements to modern extrusion machinery for silage stretch. Pages 4.1-4.20 in Proc. Agricultural Film 2012: Int. Conf. Agric. Horticultural Film Industry. Applied Market Information Ltd., Madrid, Spain.

Savoie, P. 1988. Optimization of plastic covers for stack silos. J. Agric. Eng. Res. 41:65-73.

Staples, C. 2009. Covering bunker silos with plastic. University of Florida. Accessed Aug. 30, 2013. http://animal.ifas.ufl.edu/extension/ CSFD/2009csfdpredpdf/staples09.pdf.

Tabacco, E. S. Piano, L. Cavallarin, T. F. Bernardes, and G. Borreani. 2009. Clostridia spore formation during aerobic deterioration of maize and sorghum silages as influenced by Lactobacillus buchneri and Lactobacillus plantarum inoculants. J. Appl. Microbiol. 107:1632-1641.

Tabacco, E., S. Piano, A. Revello Chion, and G. Borreani. 2011a. Effect of Lactobacillus buchneri LN4637 and Lactobacillus buchneri LN40177 on the aerobic stability, fermentation products, and microbial populations of corn silage under farm conditions. J. Dairy Sci. 94:5589-5598.

Tabacco, E., F. Righi, A. Quarantelli, and G. Borreani. 2011b. Dry matter and nutritional losses during aerobic deterioration of corn and sorghum silages as influenced by different lactic acid bacteria inocula. J. Dairy Sci. 94:1409-1419.

Wilkinson, J. M., and D. R. Davies. 2013. The aerobic stability of silage: key findings and recent developments. Grass Forage Sci. 68:1-19. 